\title{
A relativização da coisa julgada nas ações coletivas*
}

\author{
The relativization of res judicata in the collective actions
}

Fernanda Vicentini $^{1}$
Francisco Baleotti $^{2}$

\section{Resumo}

0 trabalho versa sobre o polêmico tema da relativização da coisa julgada nas ações coletivas. Num primeiro momento, procurou-se esclarecer o conceito de direito coletivo. A segunda parte é dedicada à coisa julgada, seguida pela discussão sobre a segurança jurídica. Após tecer apenas considerações gerais sobre sua formação da coisa julgada nas lides individuais, foi analisada de forma mais profunda as várias especificidades da coisa julgada coletiva, bem como a discussão sobre a possibilidade de relativizar a coisa julgada em tais ações.

Palavras Chave: Direito; Processual Civil; Coisa Julgada; Direitos Coletivos; Relativização.

\begin{abstract}
The work deals with the controversial issue of relativity of res judicata in class actions. At first, we tried to clarify the concept of collective rights. The second part is devoted to res judicata, followed by a discussion on legal certainty. After only make general remarks about his training in the cares of res judicata individual was analyzed in greater depth the various specifics of the collective res judicata, as well as discussion about the possibility of relative res judicata in such actions.
\end{abstract}

Keywords: Law; Civil Procedural; Res Judicata; Collective rights; Relativization.

\section{Introdução}

O efetivo acesso à justiça, como forma de garantia aos direitos dos cidadãos, é reconhecido como importantíssimo dentre os direitos individuais, e principalmente entre os

\footnotetext{
* Artigo resultante do projeto de pesquisa (UEL) “Acesso à Justiça: A instrumentalidade do processo frente à Jurisdição".

${ }^{1}$ M estranda em direito pela Universidade Estadual de Londrina.

${ }^{2}$ Doutor em Direito pela Pontifícia Universidade Católica de São Paulo, professor adjunto da Universidade Estadual de Londrina e professor do Fundação Educacional do Município de Assis, professor colaborador do Insituto de Direito Constitucional e Cidadania e Membro de corpo editorial da Revista Videre.
} 
direitos coletivos, considerando que qualquer titularidade de direitos é destituída de sentido se inexistirem mecanismos para sua efetiva reivindicação.

A relevância adquirida pelos direitos transindividuais evidenciou a necessidade de adequação das técnicas processuais, que antes eram marcadamente individualistas, às necessidades de uma tutela coletiva, considerando que uma inadequada utilização de institutos de caráter individual e privatísticos, quando do trato de matéria referente à coletividade, afrontam 0 princípio da efetividade e o conceito de cidadania na processualística democrática. Assim, a coletivização no tratamento das questões jurisdicionais constitui um dos recentes objetivos do processo civil na busca de resultados.

Destacando que a questão da relativização da coisa nas ações coletivas o presente trabalho estuda num primeiro momento o delineamento dos direitos transindividuais, apontando as principais características que distinguem os direitos difusos, os coletivos e os individuais homogêneos

Em seguida apresenta-se um estudo sobre a coisa julgada demonstrando sua relevância. A intangibilidade do instituto está estampada no art. 5ํ, XXXVI da Constituição Federal, em seu núcleo fundamental, constituindo-se, portanto, uma cláusula pétrea.

A coisa julgada, como garantia que se caracteriza pela autoridade de imutabilidade guarda relação direta com a efetivação da segurança jurídica, na medida em que estabiliza de forma definitiva a pacificação judicial de um conflito jurídico.

Por sua vez, o princípio da segurança jurídica é um princípio geral que abrange a segurança jurídica, ou caráter objetivo da estabilidade das relações jurídicas, e o que se denomina de proteção da confiança, caráter subjetivo .

No tópico seguinte busca-se evidenciar as questões fundamentais sobre a relativização da coisa julgada nas ações individuais.

Por fim, demonstra-se como se dá a coisa julgada no âmbito coletivo e em seguida foi trazido à colação o entendimento da doutrina acerca da relativização; discutida a necessidade ou não de relativização em ações coletivas.

\section{Dos direitos difusos, coletivos e individuais homogêneos}

Para se caracterizarem como direitos coletivos, os direitos devem possuir transindividualidade na titularidade do interesse por ele tutelado, ou seja, abandonar a visão 
tradicional, na qual a titularidade do direito apresenta-se como interesse privado ou individual, contrapondo-se aos interesses públicos e sociais.

No Brasil, foi em 1990, que a defesa dos interesses difusos, coletivos e individuais homogêneos ganhou força, com a edição da Lei 8.078 (Código de Defesa do Consumidor CDC), porém, ressalta-se que desde 1988, o art. 129, inciso III, da Constituição Federal dispõe, ainda que superficialmente, sobre os interesses difusos e coletivos ${ }^{3}$.

Imperioso destacar, num primeiro momento, que a maior parte dos doutrinadores não realiza a distinção entre as expressões "direito" e "interesse", tampouco, o legislador brasileiro a fez, conforme se extrai no art. 81 do Código de Defesa do Consumidor que, ao conceituar direitos coletivos, difusos ou individuais homogêneos, utiliza os dois termos indistintamente:

\begin{abstract}
Art. 81 - A defesa dos interesses e direitos dos consumidores e das vítimas poderá ser exercida em juízo individualmente, ou a título coletivo.

Parágrafo único - A defesa coletiva será exercida quando se tratar de: I - interesses ou direitos difusos, assim entendidos, para efeitos deste Código, os transindividuais, de natureza indivisível, de que sejam titulares pessoas indeterminadas e ligadas por circunstâncias de fato;

II - interesses ou direitos coletivos, assim entendidos, para efeitos deste Código, os transindividuais de natureza indivisível de que seja titular grupo, categoria ou classe de pessoas ligadas entre si ou com a parte contrária por uma relação jurídica-base;

III - interesses ou direitos individuais homogêneos, assim entendidos os decorrentes de origem comum.
\end{abstract}

Pedro Lenza (2005, p.55) defende inexistir qualquer relevância prática na distinção entre os termos direito e interesse, em que pese a doutrina clássica usar a terminologia "direito" para se referir a um interesse juridicamente protegido pertencente a um sujeito determinável (indivíduo). Tal fato, em princípio, levaria à conclusão da impossibilidade de se denominar de direito os interesses transindividuais, tendo em vista que ultrapassam a esfera do indivíduo.

No mesmo sentido, Kazuo Watanabe (2001, p. 739), afirma:

Os termos "interesses" e "direitos" foram utilizados como sinônimos, certo é que, a partir do momento em que passam a ser amparados pelo direito, os "interesses"

\footnotetext{
${ }^{3}$ Art. 129 - São funções institucionais do M inistério Público: (...) III - promover o inquérito civil e a ação civil pública, para a proteção do patrimônio público e social, do meio ambiente e de outros interesses difusos e coletivos.
} 
assumem o mesmo status de "direitos", desaparecendo qualquer razão prática, e mesmo teórica, para a busca de uma diferenciação ontológica entre eles.

Assim, no presente trabalho, partir-se-á da premissa de que os termos "direito" e “interesse” são sinônimos e analisar-se-á, brevemente, os interesses/direitos coletivos lato sensu, classificados em difusos, coletivos e individuais homogêneos, antes de aprofundar os estudos sobre a relativização da coisa julgada coletiva.

\section{Direitos difusos}

Analisando o disposto no art. 81, inciso I do CDC ${ }^{4}$, observa-se que os interesses ou direitos difusos apresentam as seguintes características: a) titulares indetermináveis; b) titulares ligados por uma circunstância de fato, c) direitos ou interesses indivisíveis.

Luiz Fernando Bellinetti $(2005$, p.7) conceitua os direitos difusos como “[...] os transindividuais, de natureza indivisível, que sejam pertinentes a um grupo indeterminado de pessoas, ligadas por circunstâncias de fato".

Em suma, é possível dizer que os direitos difusos são aqueles que afetam toda a coletividade em sua definição mais ampla, e cujos reflexos devem se espalhar de tal forma que dispensa uma identificação dos possíveis lesados (STAUT; VICENTINI, 2010).

Podem-se analisar tais direitos ou interesses sob dois diferentes aspectos subjetivos, um primeiro, no qual se verificam as características da indeterminação dos membros do grupo ao qual o interesse pertence, ou seja, os titulares dos direitos difusos formam uma comunidade de pessoas indeterminadas e indetermináveis. Já, o segundo aspecto subjetivo dos direitos difusos diz respeito à inexistência de relação jurídica base entre tais pessoas, ou seja, não há uma prévia circunstância jurídica entre os titulares dos direitos que estabeleça uma ligação entre as pessoas difusamente consideradas e o obrigado (STAUT; VICENTINI, 2010).

\footnotetext{
${ }^{4}$ Art. 81 - A defesa dos interesses e direitos dos consumidores e das vítimas poderá ser exercida em juízo individualmente, ou a título coletivo.

Parágrafo único - A defesa coletiva será exercida quando se tratar de:

I - interesses ou direitos difusos, assim entendidos, para efeitos deste Código, os transindividuais, de natureza indivisível, de que sejam titulares pessoas indeterminadas e ligadas por circunstâncias de fato;

$[\ldots]$
} 
No que tange ao aspecto objetivo, é característica dos direitos difusos a indivisibilidade do objeto, ou do bem jurídico tutelado, que resulta da própria natureza desses direitos que pertence a todos indistintamente, e, consequentemente, uma única ofensa prejudica, ou uma solução beneficia a todos (STAUT; VICENTINI, 2010).

Dentre os obrigados a respeitarem os interesses difusos temos os que direta ou indiretamente vendam, produzam, distribuem ou comercializam produtos ou serviços, ou seja, todos os fornecedores elencados no art. 3ํ do Código de Defesa do Consumidor ${ }^{5}$.

\section{Direitos coletivos}

0 inciso II do parágrafo único do art. 81 do Código de Defesa do Consumidor ${ }^{6}$, dispõe que os caracteres do direito coletivo em sentido estrito são: a) sujeitos determináveis; b) direitos ou interesses indivisíveis; c) titulares ligados entre si ou com a parte contrária por uma relação jurídica base.

Assim, apresenta um aspecto subjetivo, onde os titulares dos direitos coletivos são indeterminados, mas determináveis (STAUT; VICENTINI, 2010). ${ }^{7}$

Luis Fernando Bellinetti define os interesses coletivos como: "Os interesses de natureza indivisível, que sejam concernentes a um grupo, categoria ou classe de pessoas ligadas entre si ou com a parte contrária por uma relação jurídica base preexistente" (2005, p. 07).

Isso significa dizer que há uma relação jurídica base preexistente à lesão ou ameaça de lesão ao bem jurídico, entre os componentes do grupo, ou entre eles e a parte contrária. Em outras palavras, essa relação jurídica base pode ser representada por um elo existente

\footnotetext{
${ }^{5}$ Art. 30 - Fornecedor é toda pessoa física ou jurídica, pública ou privada, nacional ou estrangeira, bem como os entes despersonalizados, que desenvolvem atividades de produção, montagem, criação, construção, transformação, importação, exportação, distribuição ou comercialização de produtos ou prestação de serviços.

${ }^{6}$ Art. 81 - A defesa dos interesses e direitos dos consumidores e das vítimas poderá ser exercida em juízo individualmente, ou a título coletivo.

Parágrafo único - A defesa coletiva será exercida quando se tratar de:

[...]

II - interesses ou direitos coletivos, assim entendidos, para efeitos deste Código, os transindividuais de natureza indivisível de que seja titular grupo, categoria ou classe de pessoas ligadas entre si ou com a parte contrária por uma relação jurídica-base;

${ }^{7}$ Uma escola, cuja qualidade de ensino oferecido configura direito coletivo, ou seja, de todos os alunos indistintamente, mas que afeta cada aluno em particular.
} 
entre os próprios consumidores. ${ }^{8}$

O direito coletivo, no aspecto objetivo, protege um objeto ou bem jurídico indivisível, não pertencendo a um consumidor individual em particular, mas a todos em conjunto e simultaneamente. Se o objeto for divisível, é individual ou individual homogêneo, e não coletivo (STAUT; VICENTINI, 2010).

\section{Direitos individuais homogêneos}

Luis Fernando Bellinetti $(2005$, p.7) conceitua os direitos individuais homogêneos como "[...] os interesses divisíveis de pessoas determináveis, que o ordenamento permite serem tratados englobadamente e de forma indivisa por derivarem de uma origem comum".

As características dos direitos individuais homogêneos, que ajudam a identificá-los e a diferenciá-los dos direitos difusos e coletivos em sentido estrito são: a) titulares determinados ou determináveis; b) interesses ou direitos divisíveis; c) titulares ligados entre si por uma situação de fato ou de direito comum.

Quanto ao seu aspecto subjetivo, tem-se que nos direitos individuais homogêneos há um grupo determinado de pessoas a que diz respeito o interesse, ou seja, são direitos subjetivos individuais tratados de forma coletiva, por serem homogêneos em razão da origem comum. Em que pese a existência de mais de um titular, não se trata de litisconsórcio ativo, em que duas ou mais pessoas com direitos próprios e individuais ingressam com ação pleiteando seus direitos, mas de direito individual homogêneo, coletivo. A relação jurídica base é posterior à lesão ao bem jurídico protegido pelo interesse difuso ou coletivo, e se configura entre os membros do grupo e a parte contrária (STAUT; VICENTINI, 2010).

Segundo José Carlos Barbosa M oreirasão:

Interesses referíveis individualmente aos vários membros da coletividade atingida, e não fica excluída a priori a eventualidade de funcionarem os meios de tutela em proveito de uma parte deles, ou até de um único interessado, nem a de desembocar o processo na vitória de um ou de alguns e, simultaneamente, na derrota de outro ou de outros. 0 fenômeno adquire, entretanto, dimensão social em razão do grande número de interessados e das graves repercussões na comunidade; numa palavra: do 'impacto de massa'. (1985)

\footnotetext{
${ }^{8}$ Como exemplo o caso de uma Associação de Pais e Mestres, ou de uma Associação de Proteção ao Consumidor etc.
} 
No que tange ao aspecto objetivo, o objeto ou o bem jurídico tutelado é divisível, ou seja, os indivíduos são titulares de um mesmo direito individual homogêneo, mas o resultado real da violação é diverso para cada um, tal dano individualmente considerado será oportunamente apurado em liquidação de sentença. (STAUT; VICENTINI, 2010).

Conforme ensina Pedro Lenza:

Por seu turno, os interesses individuais homogêneos caracterizam-se por sua divisibilidade plena, na medida em que, além de serem os seus sujeitos determinados, não existe, por regra, qualquer vínculo jurídico ou relação jurídicabase ligando-os, sendo que, em realidade, a conexão entre eles decorre de uma origem comum, como, por exemplo, o dano causado à saúde individual de determinados indivíduos, em decorrência da emissão de poluentes no ar por uma indústria. Diante disso, é perfeitamente identificável o prejuízo individual de cada qual, podendo-se dividir (cindir) o interesse, efetivando-se a prestação jurisdicional de maneira correlacionada ao dano particular. $(2005$, p. 55)

Os responsáveis pelos danos causados são todos aqueles que, direta ou indiretamente, tenham causado o dano ou participado do evento danoso.

Tecidas estas breves observações, a respeito das características essenciais de cada uma das espécies de interesses coletivos lato sensu, passa-se a discorrer sobre o tema central do presente artigo.

\section{Coisa julgada}

Para que se possa garantir a paz social e por um fim ao litígio posto em juízo, é mister que, em determinado momento, o julgado proferido pelo magistrado torne-se imutável. Tal estabilidade e segurança necessárias à sociedade ocorrem com a formação da coisa julgada, ou seja, a coisa julgada apresenta-se como um comando de estabilização das relações postas em juízo, é responsável por resguardar o marco final do reclamo, garantindo a segurança jurídica e autoridade de suas decisões.

Ressalta Cândido Rangel Dinamarco:

A função da coisa julgada tout court é a de proporcionar segurança nas relações jurídicas, sabendo-se que a insegurança é gravíssimo fator perverso que prejudica os negócios, o crédito, as relações familiares e, por isso, a felicidade pessoal das pessoas ou grupos 13. (2005, p. 294) 
A coisa julgada pode ser analisada não só como garantia constitucional, mas ainda como fonte assecuratória de direitos e de situações jurídicas, bem como categoria processual (MANCUSO, 2007, p. 113).

Constitucionalmente garantida como cláusula pétrea, no artigo 60, $\S 40$ da Constituição Federal ${ }^{9}$, a coisa julgada apresenta-se ainda entre os direitos no Título II, o qual intitula-se "Dos Direitos e das Garantias Fundamentais", bem como no Capítulo I, que trata dos "Direitos e Deveres Individuais e Coletivos", no artigo 5ㅇ., XXXVI o qual assegura que :

Art. 5‥ Todos são iguais perante a lei, sem distinção de qualquer natureza, garantindo-se aos brasileiros e aos estrangeiros residentes no País a inviolabilidade do direito à vida, à liberdade, à igualdade, à segurança e à propriedade, nos termos seguintes:

(...) XXXVI - a lei não prejudicará o direito adquirido, 0 ato jurídico perfeito e a coisa julgada;

Como fonte assecuratória de direitos e situações jurídicas, a coisa julgada busca imunizar o julgado de possíveis impugnações há uma opção pela segurança como categoria processual. Ainda, sob seu aspecto jurídico, pode a coisa julgada ser vista como espécie do gênero preclusão.

o Código de Processo Civil apresentou a coisa julgada, como categoria processual, na Seção II, que contém nove artigos que vão do 467 ao 475.

Nos ensinamentos de Chiovenda, "[...] a coisa julgada é a eficácia própria da sentença que acolhe ou rejeita a demanda (...)". Apresenta a coisa julgada como a "[...] indiscutibilidade da existência da vontade concreta da lei afirmada". (2000, p. 442)

Nesse diapasão, preconizava que a sentença é a concretização da vontade do Estado e a coisa julgada será a qualidade que vai atribuir a essa sentença as características de indiscutibilidade e estabilidade.

\footnotetext{
${ }^{9}$ Art. 60. A Constituição poderá ser emendada mediante proposta:

[...]

$\S 4$ ㅇ Não será objeto de deliberação a proposta de emenda tendente a abolir:

I - a forma federativa de Estado;

II - o voto direto, secreto, universal e periódico;

III - a separação dos Poderes;

IV - os direitos e garantias individuais
} 
Ainda, observa-se que para o doutrinador é imprescindível que tenha ocorrido a preclusão de todas as questões passíveis de serem discutidas na ação (coisa julgada formal) para se operar a coisa julgada.

De outro lado Liebman, que teceu críticas ao pensamento de Chiovenda, define a autoridade da coisa julgada como a qualidade de imutabilidade do comando emergente de uma sentença. Imutabilidade "[...] é uma qualidade mais intensa e mais profunda, que reveste 0 ato também em seu conteúdo e torna assim imutáveis, além do ato em sua existência formal, os efeitos, quaisquer que sejam, do próprio ato" (2007, p. 23).

Observa-se que 0 autor defendia, portanto, que a coisa julgada será a qualidade conferida aos efeitos da sentença capaz de dotá-los de imutabilidade, intangibilidade ou imodificabilidade, visando o estabelecimento da segurança jurídica, impossibilitando que as demandas se prolonguem indefinidamente no tempo.

No mesmo sentido; Teresa Wambier e Medina (2003, p. 20), apresentam a coisa julgada como a imutabilidade do comando da sentença; Marcelo Abelha (2004, p. 253) segundo a "autoridade que imprime sobre a norma jurídica concreta"; e, Nelson Nery (2008, p. 38) conclui pela "[...] qualidade que torna imutável e indiscutível o comando que emerge da parte dispositiva da sentença de mérito não mais sujeita a recurso ordinário ou extraordinário, nem à remessa necessária", Porém, de modo diverso, Mazzilli (2006, p. 525) afirma que a coisa julgada "[...] é apenas a imutabilidade dos efeitos da sentença, adquirida com o trânsito em julgado".

Destaca-se, também, o entendimento de Ovídio Araújo Batista da Silva, para quem a coisa julgada é "[...] a própria virtude de certas sentenças judiciais, que as faz imunes às futuras controvérsias, impedindo que se modifique, ou discuta, num processo subseqüente, aquilo que o juiz tiver declarado como sendo 'a lei do caso concreto'”. (2002, p.480)

Imperioso destacar que é frequente na doutrina a distinção entre coisa julgada formal, tida como aquela formada no interior do processo, e coisa julgada material, isto é, aquela destinada a explicar a imutabilidade do comando sentencial exteriormente ao processo em que foi formada.

No plano legal, no artigo 467 do CPC, encontra-se o conceito de coisa julgada material: "Denomina-se coisa julgada material a eficácia, que torna imutável e indiscutível a sentença, não mais sujeita a recurso ordinário ou extraordinário". 
Assim, a coisa julgada material é a qualidade que torna imutável e indiscutível 0 comando da sentença, que emerge da parte dispositiva da sentença de mérito, não mais sujeita a recurso ordinário ou extraordinário, nem à remessa necessária (ALVIM, 1996, p. 103).

Para José Frederico M arques:

Na coisa julgada material, concentra-se a autoridade da coisa julgada, ou seja, o mais al to grau de imutabilidade a reforçar a eficácia da sentença que decidiu sobre o mérito ou sobre a ação, para assim impedir, no futuro, qualquer indagação sobre a justiça ou injustiça de seu pronunciamento. (1999, p. 355)

A noção de coisa julgada material é mais ampla que a formal, porque abrange além das questões endoprocessuais as extraprocessuais, impedindo a rediscussão da mesma controvérsia ainda que em outro processo.

Por sua vez, como coisa julgada formal entende-se a imutabilidade do comando normativo da sentença restrita ao mesmo processo em que foi proferida, não impedindo que o mérito da lide seja apreciado e decidido em outro processo, ou seja, ocorre quando as vias de impugnação da sentença estão preclusas, tornando imutável a decisão apenas dentro do processo no qual foi proferida.

Segundo Nery Júnior:

A denominação coisa julgada formal é equívoca, mas se encontra consagrada na doutrina. Trata-se, na verdade, de preclusão e não de coisa julgada. Não é objeto da garantia constitucional da CF 50. XXXVI, que abrange apenas a autoridade da coisa julgada (coisa julgada material). (2008, p. 682)

Para Candido Rangel Dinamarco:

0 fenômeno processual da irrecorribilidade, ou seja, da exclusão de todo e qualquer poder de provocar ou emitir nova decisão no processo, é a preclusão [...]. $\mathrm{E}$, como essa preclusão tem sobre o processo como um todo o efeito mortal de consumar sua extinção, tradicionalmente a doutrina diz proeclusio maxima para designar a coisa julgada formal. (2005, p. 296) (grifo do autor)

Defende ainda o autor que coisa julgada formal e coisa julgada material seriam dois aspectos de "[...] um único fenômeno jurídico, uma vez que, em ambos os casos, pode se 
constatar a imutabilidade ou indiscutibilidade do comando contido na decisão, ainda que em graus diversos". (DINAM ARCO, 2005, p. 296)

Limites objetivos e subjetivos da coisa julgada

Segundo 0 art. 469 CPC, não fazem coisa julgada: "(I) os motivos, ainda que importantes para determinar o alcance da parte dispositiva da sentença; (II) a verdade dos fatos, estabelecida como fundamento da sentença; (III) a apreciação da questão prejudicial, decidida incidentemente no processo".

É o autor, na petição inicial, que fixa os termos da lide, por conseqüência o juiz deve decidir a lide de acordo com esse limite, e a coisa julgada material ocorre, ainda, fadada à observância de limites objetivos e subjetivos.

Conforme se observa do artigo 469 do CPC, sob o aspecto objetivo, a coisa julgada material é limitada à matéria constante da parte dispositiva da sentença, ressalvados os casos de questão prejudicial de mérito que abarcam a parte da motivação da sentença.

No art. 468 do CPC, encontra-se o primeiro limite estabelecido e diz respeito "ao limite de lide e das questões decididas". Todas as sentenças de mérito sejam elas totais ou parciais são passíveis de gerar coisa julgada, mas é indispensável que tenha havido manifestação expressa do magistrado com relação a todas as questões para que o efeito se projete.

0 art. 470 do CPC prevê a possibilidade de a questão prejudicial ser atingida pela coisa julgada quando a parte assim o requerer e o juiz for competente para seu julgamento e estiver diretamente relacionada com o objeto do litígio. Por fim, 0 art. 471 do CPC fixa as exceções quando o magistrado poderá rediscutir questões decididas relativas à mesma lide, quais sejam: questões referentes à relações continuativas em que haja fatos supervenientes que alterem seu estado inicial e em outros casos previstos em lei.

Já no que se refere aos limites subjetivos, o foco da intangibilidade do comando da sentença direciona-se às pessoas atingidas pela decisão, e estão descritos no artigo 472 do mesmo diploma processual civil brasileiro.

Nesse sentido, a sentença faz coisa julgada só entre o demandante e o demandado (partes originárias e sucessoras, quando for o caso) e seus efeitos não alcançam outros processos. É o que Nery e Nery (2008, p. 617) denominam “[...] coisa julgada inter omnes, 
que se opõe ao sistema de coisa julgada previsto no processo coletivo o qual, conforme será abordado a seguir, será erga omnes".

Sendo a legitimação ordinária fica mais simples de identificar em regra as pessoas atingidas pelos efeitos da coisa julgada, no caso da legitimação extraordinária permitirá que pessoa diversa do titular do direito em litígio intervenha como parte no processo.

\section{Segurança jurídica e relativização da coisa julgada}

Segurança jurídica

No últimos anos, tem-se verificado a atribuição de menor valor ao instituto da coisa julgada material, seja no âmbito doutrinário, ou jurisprudencial, tal fato dá-se em decorrência da sobreposição de outras garantias fundamentais constitucionais ao princípio da segurança jurídica, que visa a estabilidade das relações, como forma de relativização da coisa julgada.

No presente tópico, será analisada a segurança jurídica, que é o embasamento jurídico da coisa julgada, conforme já constatado no item anterior.

Em linhas gerais analisar-se-á se há possibilidade de se "relativizar" a coisa julgada material por meios atípicos, ou seja, consoante Luiz Guilherme Marinoni e Sérgio Arenhart Cruz, se é possível e conveniente, "[...] diante de certas circunstâncias, dispensar a ação rescisória para abrir oportunidade para a revisão de sentenças transitadas em julgado". (2007, p. 667)

Por segurança jurídica Leonardo Greco entende:

A segurança jurídica é o mínimo de previsibilidade necessária que o Estado de Direito deve oferecer a todo cidadão, a respeito de quais são as normas de convivência que ele deve oferecer e com base nas quais pode travar relações jurídicas válidas e eficazes. (2007, p. 48)

Por consolidar a ordem jurídica positivada, a segurança jurídica é uma das vigas mestras da sustentação do Estado Democrático de Direito.

Consoante relata Fábio Rogério Teixeira Dias de Almeida Carvalho:

Neste esteio, é correto entender o corolário da Segurança Jurídica como um dos mais importantes sustentáculos sobre o qual se assenta o Estado de Direito. Ou 
ainda, como importante garantidor da paz social, na medida em que possibilita saber a todos os submetidos ao Estado o modo pelo qual serão tratadas as relações sociais que se estabelecem no convívio humano e suas implicações. (2011)

Para consecução de um Estado justo é imprescindível a segurança jurídica e a certeza do direito ao estabelecimento da ordem, para possibilitar o reconhecimento de direitos e a exigência do cumprimento de obrigações (M ARTINS, 2003)

A segurança jurídica relaciona-se fortemente com a certeza do direito, a qual, como bem aponta Habermas, é uma das formas de se garantir, verdadeiramente, a realização efetiva do Estado Democrático.

Por sua vez, o princípio da segurança jurídica é um princípio geral que abrange a segurança jurídica, ou caráter objetivo da estabilidade das relações jurídicas, e o que se denomina de proteção da confiança, caráter subjetivo .

Em que pese, não apareça de modo explícito no corpo da Constituição brasileira, 0 princípio da segurança jurídica se manifesta por meio de garantias fundamentais, como coisa julgada, a irretroatividade das leis, respeito ao direito adquirido e ao ato jurídico perfeito, a garantia de da ampla defesa, a prévia de lei que disponha sobre configuração de crimes e transgressões, a justiça social, o devido processo legal, além de outras (MARTINS); previstas no artigo 5, pelo que, são cláusulas pétreas ${ }^{10}$.

Ainda cumpre observar o embate travado entre segurança jurídica e justiça que ganhou destaque com o positivismo. Os positivistas exaltavam a segurança jurídica, tendo-a como valor fundamental. Houve um fenômeno denominado por alguns doutrinadores de "santificação da coisa julgada", onde a imutabilidade proveniente da autoridade da coisa julgada material era algo quase que absoluto.

Todavia, após a Segunda Guerra Mundial, o positivismo entrou em decadência e ocorreu uma alteração nos valores da sociedade, primando-se pela justiça e efetividade.

\footnotetext{
${ }^{10}$ Art. 60. A Constituição po derá ser emendada mediante proposta:

I - de um terço, no mínimo, dos membros da Câmara dos Deputados ou do Senado Federal;

II - do Presidente da República;

III - de mais da metade das Assembléias Legislativas das unidades da Federação, manifestando-se, cada uma delas, pela maioria relativa de seus membros.

(omissis)

$\S 4$ - Não será objeto de deliberação a proposta de emenda tendente a abolir:

(omissis)

IV - os direitos e garantias individuais.
} 
Tornou-se clara a preocupação dos modernos Estados Democráticos de Direito em criar um direito justo e o conflito entre segurança jurídica e justiça, ocorrido com o póspositivismo,

Concomitantemente, uma das transformações ocorridas foi a admissão de uma relativização da coisa julgada diante de determinadas situações.

\section{Relativização da coisa julgada}

Quando se fala em relativização da coisa julgada, busca-se na ampliar os limites de não-incidência da autoridade da coisa julgada (M OREIRA, 2007, p. 235).

Atualmente as reflexões sobre a relativização da coisa julgada dividem-se em quatro: (i) como uma forma de buscar "acertar" decisões judiciais em que se cometeram injustiças; (ii) que se mostram incompatíveis com a própria finalidade do direito, principalmente por afronta à Constituição Federal; (iii) em razão do surgimento de nova prova técnica, indisponível ao tempo do processo; (iv) hipóteses que envolvem direitos da personalidade ou fundamentais da humanidade, em que cabível ação rescisória, mas o prazo já se exauriu.

Teresa Arruda Alvim Wambier e José Miguel Garcia Medina, em sua obra intitulada "O dogma da coisa julgada: hipóteses de relativização" (2003. p. 26), resgataram algumas hipóteses que, efetivamente, não se submetem ao regime jurídico da coisa julgada, como por exemplo as sentenças juridicamente inexistentes e aquelas fundadas em cognição parcial e sumária, desmistificando a coisa julgada sem contudo, com ela romper.

Também, a relativização da coisa julgada ganhou relevo no cenário processual quando se trata da questão da injustiça do julgado e a sua não sujeição, em tese, ao regime jurídico da coisa julgada, ou em casos de aparecimento de documento novo como por exemplo, em relação ao DNA onde, tanto a doutrina quanto a jurisprudência rapidamente tenderam a se inclinar em admiti-lo como documento novo, com fundamento no art. 485, inciso VII, do CPC (WAM BIER; M EDINA, 2003, p. 170).

Considerando a "relativização" da coisa julgada material nos casos em que se verifica violação à chamada justiça das decisões, serão analisados os principais argumentos levantados favoráveis e desfavoráveis à "relativização" da coisa julgada.

Ovídio Araújo Baptista da Silva, sem externar qualquer opinião, seja positiva, identifica um movimento tendente em admitir a plena desconstituição do julgado tido como 
injusto, como um retorno a valores prémodernos do direito medieval ou mesmo romano, onde "[...] a sentença nula era de fato nenhuma (nullum), não carecendo, como o nulo moderno, ser desconstituído". (2002)

Ainda, salienta Ovídio A. Baptista da Silva:

a) o princípio da razoabilidade e da proporcionalidade deve condicionar a "imunização" dos efeitos da coisa julgada material;

b) a ofensa à moralidade administrativa deve afastar a autoridade da coisa julgada, "quandoabsurdamente lesiva ao Estado";

c) sempre que as entidades públicas sejam chamadas a pagar, nas indenizações por expropriações imobiliárias, mais do que o justo valor, a coisa julgada não terá seus efeitos "imunizados";

d) igualmente a ofensa à "cidadania e direitos do homem" deve impedir a perenização de decisões "inaceitáveis em detrimento dos particulares";

e) a garantia constitucional do meio ambiente "ecologicamente equilibrado" não pode ser desconsiderada, "mesmo em presença de sentença passada em julgado". (2002, p. 31)

Cândido Rangel Dinamarco (2005, p. 73), diante da preocupação com a justiça das decisões e a efetividade da tutela defende a "relativização" da coisa julgada, e insiste na necessidade de realizar-se uma interpretação evolutiva e sistemática dos princípios e garantias constitucionais do processo, devendo-se balancear a certeza e a justiça: "[...] algo inerente à ordem constitucional-processual, dada a imprescindibilidade de convivência harmônica com os demais valores e princípios de igual ou maior grandeza que norteiam o ordenamento".

Em oposição, Luiz Guilherme Marinoni, alega que a coisa julgada material é garantia insculpida no art. 5ำ, inciso XXXVI, da Constituição Federal, logo:

A coisa julgada não pode ser colocada no mesmo plano do direito que constitui 0 objeto da decisão à qual adere. Ela é elemento integrante do conceito de decisão jurisdicional, ao passo que 0 direito é apenas o seu objeto. Não há dúvida que os direitos podem, conforme 0 caso, ser contrapesados para fazer surgir a decisão jurisdicional adequada, mas a própria decisão não pode ser oposta a um direito, como se ao juiz pudesse ser conferido o poder de destruir a própria estabilidade do seu poder, a qual, antes de tudo, é uma garantia do cidadão.

[...]

Note-se que a idéia de se dar ao juiz o poder de balancear um direito com a coisa julgada material elimina a essência da coisa julgada como princípio garantidor da segurança jurídica, passando a instituir um sistema aberto.

Contudo, a própria razão de ser da coisa julgada impede que se imagine um sistema desse tipo, em que o juiz possa analisar, diante do caso concreto, se ela deve, ou não prevalecer. Um sistema aberto não se concilia com a natureza da coisa julgada material. Ademais, a possibilidade de o juiz desconsiderar a coisa 
julgada diante de determinado caso concreto certamente estimulará a eternização dos conflitos e colaborará para o agravamento, hoje quase insuportável, da "demora da justiça", caminhando em sentido diretamente oposto àquele apontado pela doutrina processual contemporânea. (2004, p. 30)

Em sua crítica generalista desfavorável a relativização, Marinoni acaba por injustiça àqueles, por exemplo, que com base na constituição buscam a justiça, a partir da consagração dos direitos fundamentais do homem (apud GARCIA,2004).

Luiz Guilherme Marinoni, destaca a dificuldade de se compatibilizar essa relativização da coisa julgada a partir de um critério de justiça da decisão sem que abalemos o princípio da segurança que é inerente à própria noção de jurisdição e de Estado Democrático de Direito.

0 fato de se acolher a tese da "relativização" da coisa julgada não significa, necessariamente, que a segunda decisão será mais justa, no aspecto material, mesmo porque, a justiça plena é algo inalcançável, "[...] haja vista que o ser humano, a quem cabe a aplicação do direito, não é infalível ou sobrenatural como o juiz Hércules, a que alude Dworkin [...]" (apud RAM OS, 2007). Aliás, nem mesmo o Juiz Hércules estará em condições de encontrar para cada caso uma resposta verdadeira, pois aquela que seria a única resposta correta simplesmente não existe.

\section{Relativização da coisa julgada coletiva}

Coisa julgada nas ações coletivas

A coletivização no tratamento das questões jurisdicionais constitui um dos recentes objetivos do processo civil de resultados.

0 reconhecimento e a relevância dos direitos supraindividuais evidenciaram a necessidade de adequação da técnica processual, marcadamente individualista, às necessidades de uma tutela coletiva, já que a inadequada utilização de institutos de caráter privatístico e individual quando do trato de matéria referente à coletividade, afrontam 0 princípio da efetividade e o conceito de cidadania na processualística democrática.

É sabido que referidas leis, que regulam as ações coletivas inovaram aspectos processuais e procedimentais. Neste desiderato, muitos destacaram a coisa julgada como um dos pontos mais delicados na tutela desses direitos. 
Em 1997 o Poder Executivo editou a MP no. 1.570 que, após sua quinta edição, converteu-se na Lei no. 9.494/97 e alterou 0 art. 16 da LACP para restringir os efeitos das sentenças coletivas aos limites da competência territorial do órgão prolator da decisão como uma fórmula restritiva da eficácia extensiva da coisa julgada coletiva ao tentar limitar sua eficácia erga omnes.

Referida restrição pretendida, caminha na contramão da história, pois limita 0 acesso ao Judiciário, desconsidera o valor igualdade, reduz a participação democrática por meio dos corpos intermediários e inibe o papel da jurisdição como elemento de inclusão social.

Conforme já estudado a coisa julgada individual caracteriza-se por ser inter partes e pro et contra ${ }^{11}$.

No direito coletivo a coisa julgada é secundum eventum probationis, conforme prevista nos arts. 18 da LAP e 16 da LACP, ou seja, em caso de insuficiência de provas não se daria a coisa julgada material, podendo ser reproposta a demanda.

Também o CDC consagra a coisa julgada secundum eventum probationis para ações coletivas que versam sobre direitos difusos ou coletivos stricto sensu. Apenas se forma caso a demanda seja julgada procedente ou improcedente por insuficiência de provas e nos casos de improcedência da ação fundamentada no art. 267 do CPC. Se a decisão no processo coletivo julgar improcedente a demanda por insuficiência de provas não fará coisa julgada. Referida insuficiência de provas deve constar ou defluir da decisão, sendo este o parâmetro decisivo para viabilizar-se a propositura da mesma demanda, calcada em nova prova. Esse é o teor do disposto no inc. II, do art. 103, do CDC.

Ainda, o CDC atendendo às garantias individuais, dita que, não serão prejudicadas as ações individuais em razão do insucesso da ação coletiva, sem a anuência do indivíduo. Ocorre a extensão secundum eventum litis da coisa julgada coletiva ao plano individual. Assim, as sentenças apenas terão estabilizadas suas eficácias com relação ao substituídos quando forem de procedência nas ações coletivas, ou seja, improcedência de uma ação coletiva poderia ser estabilizada pela coisa julgada material apenas no âmbito da tutela coletiva sem repercutir na tutela individual.

\footnotetext{
${ }^{11}$ Pro et contra, porque ocorre tanto para o benefício do autor, com a procedência da demanda que confirma a sua pretensão, como em seu prejuízo, com a declaração negativa de seu direito.
} 
Por sua vez, Velloso (1989, apud TEIXEIRA 1990, p. 96) não admite a extensão da coisa julgada secundum eventum litis, tende pela extensão erga omnes da eficácia da sentença, tendo em vista a segurança jurídica e o risco de exposição infinita do réu em ações coletivas inclusive na improcedência.

No direito brasileiro a extensão da coisa julgada será secundum eventum litis, porém, a extensão subjetiva do julgado em ações coletivas ocorrerá em direta relação com a amplitude do direito posto em causa.

Quando se tratar de direito difuso, a extensão será erga omnes para atingir a massa indeterminada de sujeitos. Por sua vez, sendo o direito coletivo stricto sensu, a extensão será ultra partes, atingindo a todos os membros da categoria, classe ou grupo identificáveis em razão da relação jurídica-base entre si ou com a contraparte anterior à lesão. Por fim, se tais direitos forem individuais homogêneos, a extensão será erga omnes, atingindo a todos aqueles que comprovarem a lesão do direito debatido em juízo. Ressalta-se mais uma vez que, os direitos difusos e coletivos discutidos na causa serão atingidos pela imutabilidade da coisa julgada, mas as ações e direitos individuais dos substituídos não serão prejudicados.

Imperioso mencionar o artigo art. 103, § 3o, do CDC, a ampliação ope legis do objeto do processo nas ações coletivas, de modo a autorizar o transporte in utilibus da coisa julgada para as demandas individuais.

Observa-se que regramento da coisa julgada coletiva está satisfatoriamente regulado no Código do Consumidor que assume caráter de norma geral, porém, é importante observar que se 0 interesse coletivo tutelado possuir legislação específica, esta deve ser consultada antes do microssistema coletivo.

Relativização da coisa julgada nas ações coletivas

Conforme supra descrito, o CDC e as outras leis do microssistema dispõem não fazer coisa julgada a sentença baseada em insuficiência de provas, surge então o questionamento se estariam eles admitindo uma relativização, desde que com novas provas.

Para Barbosa Moreira (2007, p. 235) a sentença que julga improcedente direito coletivo fundada em pequeno conjunto probatório, é uma das circunstâncias legalmente contempladas de relativização da coisa julgada, ou seja, a própria a norma excluiria a incidência da coisa julgada material, mesmo existindo ali mérito processual (art. 471 CPC) 
Assim, não faz coisa julgada a sentença que julga improcedente direitos difusos ou coletivos por não haver suficiência de provas, de forma que fica admitida a repetição da ação, desde que com nova prova. No que se refere essa, nova prova, seria aquela preexistente, tal qual o conceito de documento novo do art. 485, VII, ou seja, aquela que já existia ao tempo da ação, mas a parte não pôde fazer uso por desconhecê-lo ou por não possuí-lo?

Segundo Marcelo Abelha (2004, p. 234) 0, tanto faz, termo "nova prova" quer significar tanto aquela surgida após o trânsito em julgado do processo anterior, como aquelas já existentes, mas que não foram levadas aos autos.

Todavia, existem outras situações que podem extrapolar a utilização da ação rescisória, especialmente nos processos coletivos. Assim, existe também, a possibilidade de insurgir-se contra a coisa julgada em caso de justiça da decisão ou sua constitucionalidade ou se esta tese traz insegurança ao meio jurídico, na medida em que todos aqueles que se sentissem demasiadamente injustiçados almejariam rediscutir sua questão, causando descrença na autoridade das decisões judiciais.

José Augusto Delgado, um dos defensores da relativização da coisa julgada, entende que "[...] nenhum órgão do Estado, situe-se ele no Poder Judiciário, ou no Poder Executivo, ou no Poder Legislativo, está imune, sob qualquer pretexto, à força da Constituição" (2011), por isso busca "[...] desmistificar o que tradicionalmente foi considerado como sendo absoluto os efeitos da coisa julgada, por mais absurda que fosse a decisão nela contida" (2011). Para tanto, discorre:

Inconcebível, em face dessas idéias hoje vigorantes no Estado Democrático de Direito, a continuidade do pensamento de que a coisa julgada é intangível, mesmo quando constituída em evidente confronto com postulados, princípios e regras da Constituição Federal. A missão dos Poderes Executivo, Legislativo e Judiciário, especialmente deste, é fazer prevalecer a força da Constituição. Esta, sozinha, por si, nenhum efeito produz. A eficácia e efetividade dos seus postulados, dos seus princípios e das suas regras dependem da atuação de todos os Poderes, com destaque, do Poder Judiciário. Em assim sendo, não é concebível, sob o simples argumento da intangibilidade da coisa julgada, aceitar-se descumprimento da Constituição Federal. (DELGADO, 2011)

Porém, posição de que a coisa julgada deve perder seu valor absoluto não parece a mais acertada. 
É necessária a consideração dos valores segurança jurídica e justiça, ou seja, quaisquer decisões injustas devem ser passíveis de correção? Nem sempre é razoável colocar em xeque a coerência e a estabilidade do sistema processual, colocar em risco a segurança porque em algumas situações específicas, decisões injustas permanecem no mundo (M OREIRA, 2007, p.242).

Para Barbosa M oreira (2007, p. 243), “[...] a lei dá ampla oportunidade de prova, de revisão de decisões, porém, há um momento em que à preocupação de fazer justiça se sobrepõe a de não deixar que o litígio se eternize". Por isso, explica o autor que não se pode querer justificar a relativização com a mera invocação de eventual injustiça na sentença ou injustiça grave.

Hugo Nigro Mazzilli, entende que além das exceções já apresentada, há casos que por envolverem direitos fundamentais da pessoa ou da humanidade que o valor absoluto da coisa julgada deve ser revisto. Ainda, na tentativa de ampliar rol de circunstâncias que possam ser novamente discutidas em juízo o autor aponta a seguinte situação:

Uma ação civil pode hoje resultar em improcedência, não por falta de provas, mas porque 0 juiz, desconsiderando a perícia, erroneamente entendeu que o resíduo emitido pela chaminé da fábrica do réu não é poluente; antes, conclui a sentença, o resíduo é saudável ou pelo menos inócuo para o homem. Formada a coisa julgada com eficácia erga omnes, e vencida a oportunidade da rescisória, será que a humanidade ficará eternamente condenada a suportar aqueles resíduos altamente tóxicos e prejudiciais? Pode ainda ocorrer que a sentença tenha sido dada por corrupção do juiz, e, embora as provas da corrupção já fossem conhecidas, pode já ter decorrido o prazo decadencial de dois anos para propor a ação rescisória. 0 que fazer? (MAZZLLI, 2006, p. 544)

Conclui o autor que "não se pode admitir coisa julgada ou direito adquirido contra direitos fundamentais da humanidade". (M AZZLLI, 2006)

Apenas os casos realmente dotados de características especiais, entre os quais se destacam as decisões sobre direitos difusos, devido ao fato de ser um direito de toda a coletividade, seria possível mitigar a coisa julgada.

Diante de todo o exposto, entende-se que a desconstituição da coisa julgada, diante de decisões contrárias à justiça, nem sempre poderá ser viável, sob pena de os conflitos tornarem-se eternos, ressaltando mis uma vez que a coisa julgada é atributo indispensável ao Estado Democrático de Direito e à segurança das relações jurídicas. 


\section{Conclusão}

A sociedade modifica-se constantemente. Em princípio, predominavam as relações interindividuais. Com o tempo passaram a reconhecer a existência da chamada "sociedade de massa", em que a produção, o consumo, a troca de bens, a prestação de serviços, a informação, a comunicação etc. ocorriam em grande escala.

Surgiu então, uma nova categoria de direitos/interesses que passaram a ser chamados de interesses coletivos, caracterizados pela transindividualidade.

No início, para solução dos conflitos transindividuais, houve uma tentativa de adaptação das regras processuais individuais ao processo coletivo. Posteriormente, a necessidade cada vez mais premente do estudo do direito material e processual coletivo, levou a criação de leis esparsas que já apresentam extensos apontamentos acerca do direito coletivo, formando um microssistema.

Na formação do moderno Estado de Direito, individualista e liberal, a segurança jurídica assumiu o papel de um valor formador do direito e da estruturação social uma vez que carece de sentido a formação de um Estado voltado para a criação e positivação de um determinado número de direitos individuais, se os cidadãos não gozam da devida segurança para fruir adequadamente esses direitos

A coisa julgada nas ações coletivas é disciplinada pelo artigo 103 do Código de Defesa do Consumidor em razão da interação existente entre o CDC (art. 90) e a LACP (art.21).

A relativização da coisa julgada nas ações coletivas vem sendo proposta por alguns doutrinadores sob o argumento de que ao lado da segurança jurídica proporcionada pela coisa julgada, outros valores de ordem constitucionais também devem ser protegidos.

\section{Referências}

ALVIM, Thereza. 0 direito processual de estar em juízo. São Paulo: Editora Revista dos Tribunais, 1996.

ABELHA RODRIGUES, M arcelo. Ação civil pública e meio ambiente. 2. ed. Rio de Janeiro: Forense Universitária, 2004. 
BARROS, Evandro Silva. A coisa julgada inconstitucional e limitação temporal para a propositura da ação rescisória. Revista de direito constitucional e internacional, São Paulo, no 47 , p. 55-98, abr.-jun. 2004

BELLINETTI, Luiz Fernando.Definição dos interesses difusos, coletivos em sentido estrito e individuais homogêneos. In Estudos de Direito Processual Civil, Ed. RT, 2005. P. 666/671.

CARVALHO, Fábio Rogério Teixeira Dias de Almeida. Agências Reguladoras e o Princípio da Segurança Jurídica. Disponível em:

http://www.institutoprocessus.com.br/v_6/revista/mostrar.php?codigo=4>. Acesso em: 25 Julho 2011.

CHIOVENDA, Giuseppe. Instituições de direito processual civil. 2. ed. São Paulo: Bookseller, 2000, v. I, II e III.

DELGADO, José Augusto. Reflexões contemporâneas sobre a flexibilização, revisão e relativização da coisa julgada quando a sentença fere postulados e princípios explícitos e implícitos da Constituição Federal: manifestações doutrinárias. Disponível em: ४ttp://bdjur.stj.gov.br>. Acesso em: 20 julho. 2011.

DINAM ARCO, Cândido Rangel. Instituições de direito processual civil, volume III. 5. ed. rev. e atual. de acordo com a emenda constitucional n. 45 de 8.12.2004. São Paulo: M alheiros, 2005.

GARCIA, Maria. A inconstitucionalidade da coisa julgada. Revista de direito constitucional e internacional, São Paulo, no 47, p. 48-54, abr.-jun. 2004.

LENZA, Pedro. Teoria geral da ação civil pública. 2. ed. São Paulo: Revista dos Tribunais, 2005.

LIEBM AN, Eurico Tullio. Eficácia e autoridade da sentença e outros escritos sobre a coisa julgada. Tradução de Alfredo Buzaid e Benvindo Aires. (Tradução dos textos posteriores à edição de 1945 com notas relativas ao direito brasileiro vigente de Ada Pellegrini Grinover). 4. ed. Rio de Janeiro: Forense, 2007

M ANCUSO, Rodolfo de Camargo. Jurisdição coletiva e coisa julgada. São Paulo: Revista dos Tribunais, 2007.

M ARINONI, Luiz Guilherme. O princípio da segurança dos atos jurisdicionais (a questão da relativização da coisa julgada material). Revista Jurídica, Porto Alegre, no 317, mar. 2004

, Luiz Guilherme; ARENHART, Sérgio Cruz. Curso de processo civil, volume 2:processo de conhecimento. 6. ed. rev., atual. e ampl. da obra Manual do processo de conhecimento. São Paulo: Editora Revista dos Tribunais, 2007 
M ARQUES, José Frederico. Instituições de direito processual civil. v. 5. Campinas: Millenium, 1999

M ARTINS, Eliezer Pereira. Segurança jurídica e certeza do direito em matéria disciplinar. Aspectos atuais. Jus Navigandi, Teresina, ano 7, n. 63, mar. 2003. Disponível em: http://jus2.uol.com.br/doutrina/texto.asp?id=3852>. Acesso em: 16 Julho, 2011.

M AZZLLI. A defesa dos interesses difusos em juízo: meio ambiente, consumidor, patrimônio cultural, patrimônio público e outros interesses. 19ą. ed. São Paulo: Saraiva: 2006.

M OREIRA, José Carlos Barbosa.Tutela Jurisdicional dos Interesses Coletivos ou Difusos. Revista de Processo, São Paulo, ano X, no 39, p. 55-77. julho-setembro 1985 , José Carlos Barbosa .Considerações sobre a chamada "relativização" da coisa julgada material. Temas de direito processual: Nona série. São Paulo: Saraiva, 2007.

NERY JÚNIOR, Nelson, NERY, Rosa M aria de Andrade. Código de Processo Civil comentado e legislação processual civil extravagante em vigor. 10ạ. ed. São Paulo: RT, 2008.

RAM OS, André Luiz Santa Cruz. Coisa Julgada Inconstitucional. Salvador: Edições JusPodivm, 2007

SILVA, Ovídio Araújo Batista da. Curso de processo civil: processo de conhecimento. v.1. 6. ed. rev. e atual. com as Leis 10.352, 10.358/2001 e 10.444/2002. São Paulo: Editora Revista dos Tribunais, 2002.

STAUT, Maria Gabriela; VICENTINI, Fernanda. A liquidação e a execução da sentença que tutela direitos individuais homogêneos: o Fuid recovery do Direito brasileiro. In: Anais do XIX Congresso Nacional do CONPEDI. Tema: "Desafios da Contemporaneidade do Direito: diversidade, complexidade e novas tecnologias." Florianópolis - SC , 2010, p. 9680-9700

TEIXEIRA, Sálvio Figueiredo. M andados de segurança e de injunção. São Paulo: Saraiva, 1990.

WAM BIER, Teresa Arruda Alvim; M EDINA, José M iguel Garcia M edina. 0 dogma da coisa julgada: hipóteses de relativização. São Paulo: Revista dos Tribunais, 2003.

WATANABE, Kazuo. Código Brasileiro de Defesa do Consumidor, comentado pelos autores doAnteprojeto. 7. ed. Rio de Janeiro: Forense Universitária, 2001. 
Artigo recebido em:

25 de agosto de 2011

Artigo aprovado em:

06 de setembro de 2011 